\title{
SMART PARKING SYSTEM DENGAN SISTEM RESERVASI
}

\author{
Nopi Ramsari ${ }^{\# 1}$, Suharjanto Utomo ${ }^{* 2}$ \\ \# Universitas Nurtanio Bandung \\ Jl. Pajajaran No. 219 Bandung, Jawa Barat, Indonesia \\ nopiramsarihatta@gmail.com
}

Accepted on May 14, 2019

\begin{abstract}
Abstrak
Area Parkir sudah menjadi kebutuhan bagi masyarakat perkotaan, terutama dibutuhkan ditempattempat umum seperti mall, tempat wisata/rekreasi, bandara, perkantoran, hotel, kampus dan lainlain. Karena terbatasnya area parkir sehingga menyebabkan pencarian area parkir sulit karana ketidaktahuan dimana tempat parkir yang tersedia karena kurangnya informasi slot parkir mana yang penuh atau kosong sehingga dapat menyebabkan kemacetan, polusi, pemborosan bahan bakar dan tentunya kadangkala banyak memakan waktu dan tenaga. Seiring dengan kemajuan Teknologi maka terdapat sejumlah sistem yang dapat mengautomasikan pengelolaan parkir, namun hal ini masih belum diimbangi dengan manajemen dalam pencarian spot parkir karena belum adanya verifikasi pengemudi akan parkir atau tidak. Dengan menerapkan sensor RFID pada sistem parkir, sehingga sistem memberikan peringatan kepada pengemudi apabila tidak berhak untuk parkir, pengemudi dapat melakukan reservasi/pemesanan tempat parkir melalui sistem, selain itu juga sistem dapat memberikan notifikasi kepada petugas parkir. Dengan aplikasi smartparking ini diharapkan pengguna jasa parkir dapat mengetahui lokasi slot parkir yang kosong dan dapat digunakan untuk parkir dengan cepat sehingga dapat meningkatkan efisiensi tenaga dan waktu
\end{abstract}

Keywords: parkir, smartparking, RFID, slot parkir

\section{PENDAHULUAN}

A rea parkir sudah menjadi kebutuhan bagi masyarakat, khususnya masyarakat perkotaan. Area parkir sangat dibutuhkan terutama ditempat-tempat umum seperti mall, tempat wisata/rekreasi, bandara, perkantoran, hotel, kampus dan lain-lain. Pencarian area parkir yang tersedia di perkotaan sangat penting, karena selain menghabiskan banyak waktu, berpengaruh besar pula terhadap tingkat kemacetan, polusi dan pemborosan bahan bakar. Menurut survey ${ }^{[1][2]}$ menunjukkan bahwa pada saat jam sibuk, 40\% kemacetan diakibatkan oleh pencarian tempat parkir. Menemukan tempat parkir pada jam sibuk menyulitkan pengemudi. Kesulitan muncul karena ketidaktahuan dimana tempat parkir yang tersedia pada saat itu yang diakibatkan oleh kurangnya informasi tentang area parkir mana yang kosong dan terisi. Hal ini menyebabkan pengguna jasa parkir akan terjebak di lokasi perparkiran dan harus mencari lokasi parkir lainnya yang tentunya kadang kala banyak memakan waktu dan tenaga.

Dewasa ini dengan bertambahnya maju teknologi, terdapat sejumlah sistem informasi parkir ${ }^{[3]}$ yang dapat mengautomasikan pengelolaan parkir, seperti pencatatan plat nomor kendaraan, pencatatan waktu masuk, pencatatan waktu keluar, hingga pencatatan jumlah mobil yang masuk dan kapasitas parkir yang 
tersisa. Namun hal ini masih belum diimbangi dengan manajemen dalam pencarian spotparkir yang efektif seperti belum adanya verifikasi apakah pengemudi yang hendak parkir dapat parkir di tempat tersebut. Sehingga seringkali terjadi konflik antara pengemudi karena berebut tempat parkir.

Solusi yang ditawarkan dengan menerapkan sensor RFID ${ }^{[1]}$ pada sistem, sehingga sistem dapat mengetahui siapa yang parkir, dapat memberi peringatan kepada pengemudi apabila tidak berhak dan dapat memberi notifikasi kepada petugas parkir. Selain sensor RFID pada sistem juga terdapat sensor ultrasonik untuk mendeteksi kendaraan parkir ditempat parkir. Selain itu Smart Parking System juga tersedia fitur Reservasi dimana pengemudi melakukan pemesanan tempat parkir melalui sistem. Dengan aplikasi smart parking ini, diharapkan pengguna jasa parkir dapat mengetahui lokasi area parkir yang dapat digunakan dengan cepat sehingga dapat meningkatkan efisiensi tenaga dan waktu.

\section{TINJAUAN PUSTAKA}

\section{A. Skenario Manajemen Parkir}

Pada bagian ini kita akan membahas beberapa pendekatan parking guidence dan menjelaskan limitasi nya.

a) Blind Search : Blind searching adalah strategi sederhana yang digunakan pengemudi ketika tidak mengetahui informasi parkir. Dalam kasus ini, pengemudi akan terus berkendara untuk mencari tempat parkir hingga diketemukan. Bila tidak, pengemudi akan mencari di area parkir lain.

b) Parking Information Sharing (PIS) : Mekanisme ini biasanya diterapkan pada desain sistem Smart Parking. Informasi mengenai ketersediaan tempat parkir kepada pengemudi pada area tertentu, pengemudi akan menentukan dimana mereka akan parkir berdasarkan informasi tersebut. tetapi jumlah ketersediaan parkir akan terbatas pada jam jam sibuk, sehingga akan terjadi rebutan tempat parkir.

c) Buffered PIS (BPIS) Untuk mengatasi masalah rebutan parkir, beberapa desainer akan modifikasi mekanisme PIS. Yaitu dengan sengaja menampilkan informasi jumlah parkir yang tersedia lebih kecil dari kenyataan, yang berfungsi sebagai buffer. Sehingga sistem memiliki extra tempat parkir untuk menghindari konflik. Tetapi sulit untuk menentukan jumlah buffer space, jika terlalu kecil, akan tetap terjadi rebutan parkir. Bila terlalu besar, efisiensi akan berkurang.

Untuk mengatasi kelemahan kelemahan diatas, kita menawarkan Sistem Reservasi, dimana pengemudi dapat melakukan booking tempat parkir melalui Parking management System. Jika pengendara berhasil melakukan reservasi, maka dapat dipastikan akan tersedia tempat parkir untuknya, dan pengendara tidak perlu melakukan pencarian lagi.

\section{B. Internet Of Things (IOT)}

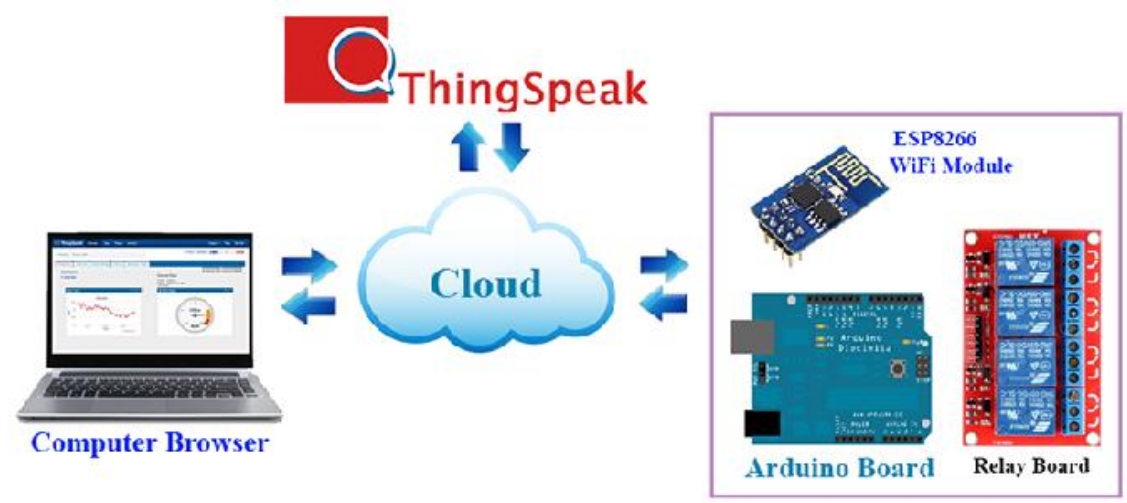

Gambar 1. Topologi Intenet Of Things 
Pada gambar 2.1 terlihat topologi dari Internet of Things [6] yang dimana terdapat beberapa elemen penting agar dapat bekerja seperti PC Client, Server, SmartPhone, dan Alat yang akan dikontrol / dimonitor seperti Arduino. PC Client dan Smart Phone berfungsi sebagai pengontrol atau yang memonitor alat. Yang dimana disetiap elemen harus terhubung dengan Internet agar komunikasi antara PC Client / Smart Phone dan Alat yang dikontrol dapat bekerja.

\section{Arduino Uno}

Arduino Uno adalah board berbasis mikrokontroler pada ATmega328 yang memiliki 14 pin digital input / output (dimana 6 pin dapat digunakan sebagai output PWM), 6 input analog, $16 \mathrm{MHz}$ osilator kristal, sebuah koneksi USB, sebuah konektor sumber tegangan, sebuah header ICSP, dan sebuah tombol reset. Arduino Uno memuat segala hal yang dibutuhkan untuk mendukung sebuah mikrokontroler. Hanya dengan menghubungkannya ke sebuah komputer melalui USB atau memberikan tegangan DC dari baterai atau adaptor AC ke DC sudah dapat menggunakannya.

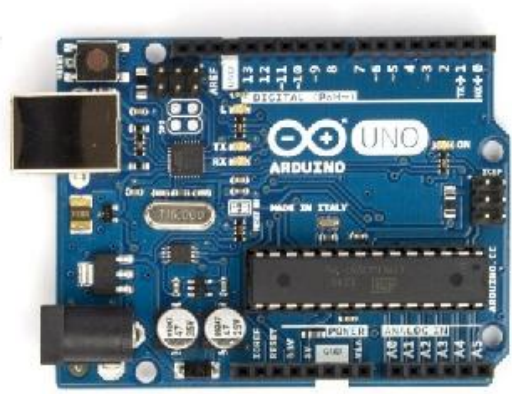

Gambar 2. Arduino Uno

\section{MicroController Unit ESP8266}

ESP8266 adalah chip Wi-Fi murah dengan penuh TCP / IP stack dan kemampuan MCU (Micro Controller Unit) yang diproduksi oleh produsen Cina yang berbasis di Shanghai, Espressif Systems. ESP8266EX adalah salah satu chip Wi-Fi yang paling terintegrasi di dunia industri. Berukuran hanya $5 \mathrm{~mm} \mathrm{x}$ 5mm, ESP8266EX membutuhkan sirkuit minimal dalam eksternal dan mengintegrasikan 32-bit Tensilica dalam menerima amplifier, filter dan modul manajemen daya semua dalam satu paket kecil . MCU, standar antarmuka digital perifer, switch antena, RF balun, power amplifier, kebisingan rendah

Chip pertama pada Agustus tahun 2014 dengan modul ESP-01, dibuat oleh produsen pihak ketiga. Modul kecil ini memungkinkan microcontrollers untuk menghubungkan ke jaringan Wi-Fi dan membuat koneksi TCP/IP sederhana menggunakan perintah bergaya Hayes. Namun, pada waktu itu hampir tidak ada bahasa dokumentasi pada chip dan perintah itu dapat diterima. Harga sangat rendah dan kenyataan bahwa sangat sedikit komponen eksternal pada modul yang disarankan, hal itu akhirnya bisa menarik banyak hacker untuk mengeksplorasi modul, chip dan perangkat lunak pada saat itu, serta sulit untuk menerjemahkan Cina dokumentasi.

ESP8266 dengan $1 \mathrm{MiB}$ built-in flash, yang memungkinkan untuk chip tunggal perangkat mampu menghubungkan ke Wi-Fi.Penerus chip mikrokontroler ini adalah ESP32. 


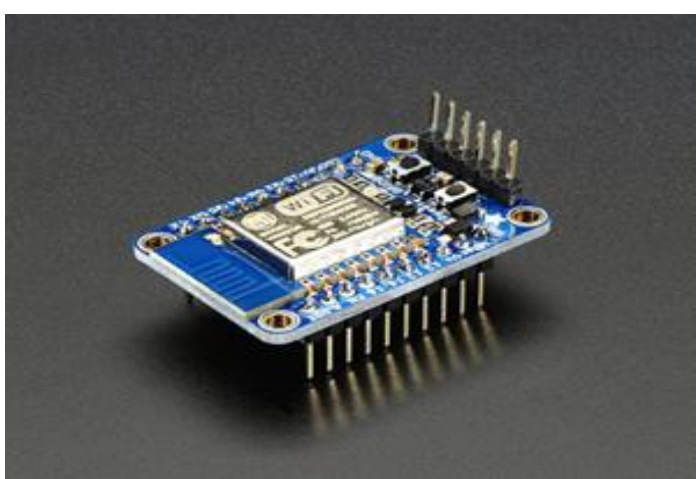

Gambar 3. Mikrocontroller ESP8266

\section{E. Sensor jarak}

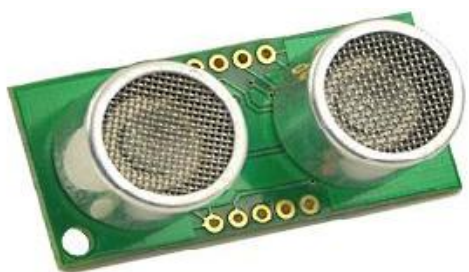

Gambar 4. Sensor jarak

Sensor jarak adalah sebuah sensor mampu mendeteksi keberadaan benda di dekatnya tanpa kontak fisik. Sensor jarak sering memancarkan elektromagnetik atau berkas radiasi elektromagnetik (inframerah, misalnya), dan mencari perubahan dalam bidang atau sinyal kembali. Objek yang sedang merasakan sering disebut sebagai sensor jarak target itu. Jarak target berbeda permintaan sensor yang berbeda. Sebagai contoh, sebuah sensor kapasitif atau fotolistrik mungkin cocok untuk target plastik, sebuah sensor jarak induktif memerlukan target logam.

Sensor jarak disesuaikan dengan rentang yang sangat singkat sering digunakan sebagai saklar sentuh. Sensor jarak dibagi dalam dua bagian dan jika kedua bagian menjauh dari satu sama lain, maka sinyal diaktifkan

\section{F. RFID}

RFID adalah kepanjangan dari Radio Frequency IDentification. RFID merupakan sebuah perangkat elektronik yang di dalamnya terdapat sebuah chip kecil dan sebuah antena. Chip berfungsi untuk menyimpan data dalam ukuran yang kecil berkisar kurang lebih 2.000 bytes data dan antena berfungsi untuk memancarkan atau menerima sinyal. RFID itu sendiri terdapat 2 elemen yaitu RFID Reader dan RFID Tag.

Ada tiga bagian bagaimana RFID dapat bekerja, antara lain:

1) Proses pemindaian antena

2) Proses pengiriman/penerimaan data ke decoder untuk diterjemahkan datanya

3) Proses penguatan sinyal dari RFID tag dan pembacaan informasi yang telah diprogram pada RFID tag. 
G. RFID Reader

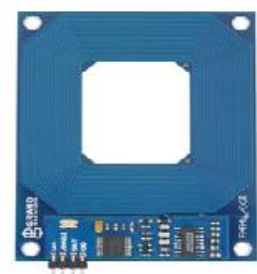

\section{Gambar 5. RFID Reader}

RFID Reader adalah merupakan alat pembaca RFID TAG. Ada dua macam RFID READER yaitu READER PASIF (PRAT) dan READER AKTIF (ARPT).

READER PASIF memiliki sistem pembaca pasif yang hanya menerima sinya radio dari RFID TAG AKTIF (yang dioperasikan dengan battery/sumber daya). Jangkauan penerima RFID PASIF bisa mencapai 600 meter. Hal ini memungkinkan aplikasi RFID untuk sistem perlindungan dan pengawasan aset.

READER AKTIF memiliki sistem pembaca aktif yang memancarkan sinyal interogator ke TAG dan menerima balasan autentikasi dari TAG. Sinyal interogator ini juga menginduksi TAG dan akhirnya menjadi sinyal DC yang menjadi sumber daya TAG PASIF.

\section{METODE PENELITIAN}

Penelitian ini menggunakan metode Pengembangan Aplikasi, Metodologi yang dipakai dalam pembuatan penelitian ini yaitu metode prototype[4]. Prototype adalah bagian dari produk yang mengekspresikan logika maupun fisik antarmuka eksternal yang ditampilkan

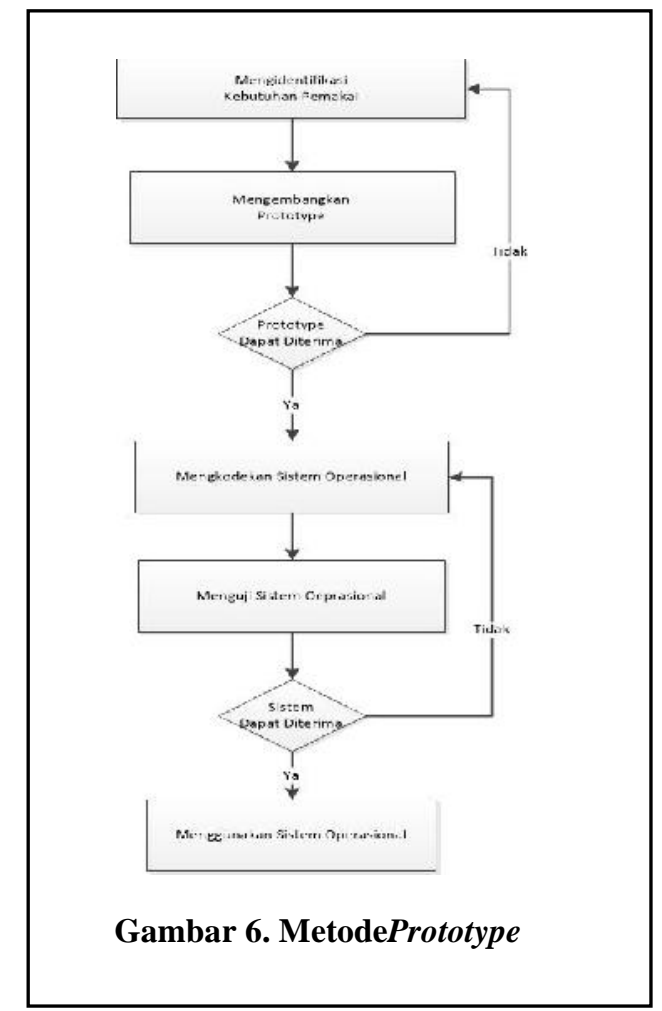




\section{DESAIN CYBER PHYSICAL SYSTEM}

\section{A. Analisis Masalah}

Sistem Parkir di saat ini masih menggunakan cara konvensional, hal ini disebabkan karena banyaknya jumlah kendaraan yang tidak sebanding dengan kapasitas maksimum spot parkir sehingga membuat sistem perparkiran masih dilakukan secara manual/konvensional dengan jumlah yang tidak berimbang antara jumlah spot parking dengan jumlah kendaraan, hal ini mengakibatkan adanya kemacetan yang disebabkan oleh ketidaktahuan dimana tempat parkir yang tersedia pada saat itu karena kurangnya informasi tentang area/slot parkir mana yang kosong dan terisi sehingga menyebabkan pengguna jasa parkir akan terjebak di lokasi perparkiran dan harus mencari lokasi parkir lainnya yang tentunya kadang kala banyak memakan waktu dan tenaga.

\section{B. Arsitektur Sistem}

Arsitektur sistem adalah istilah untuk menyatakan bagaimana mendefinisikan komponen-komponen yang lebih spesifik secara terstruktur. Dalam komputer, terdapat 2 buah perangkat yaitu : hardware (perangkat keras) dan software (perangkat lunak).

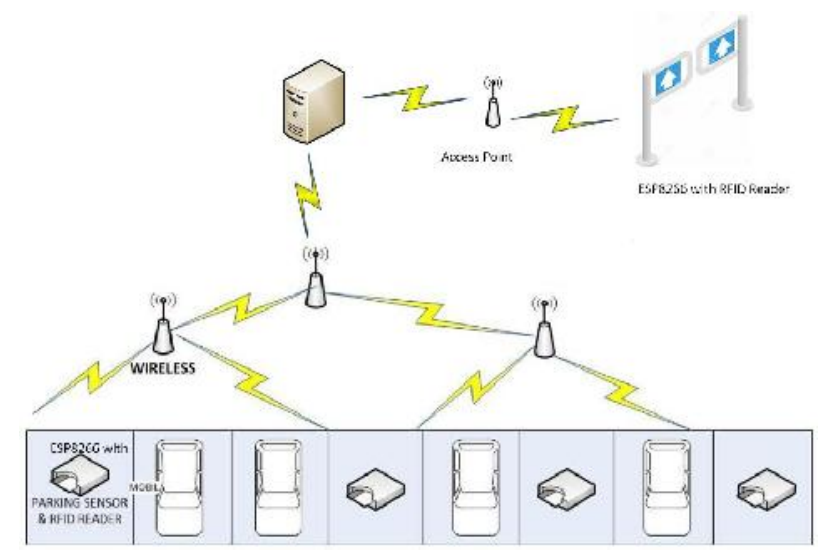

Gambar 7. Arsitektur Sistem

C. Model Use Case Diagram

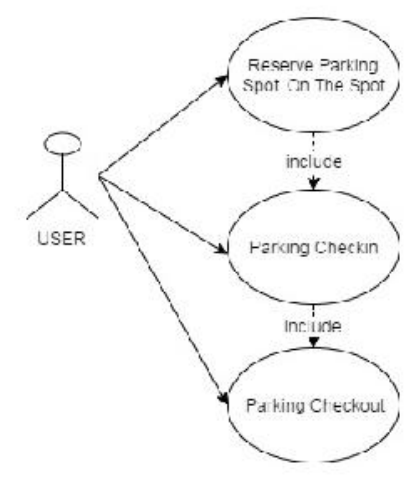

Gambar 8. Model Use Case 
Sistem smart parking ini terdiri dari satu aktor yaitu User, dimana user adalah pengguna jasa parkir Sistem ini terdiri dari tiga case :

a) Reserve Parking On the spot : Melakukan reservasi tempat parkir langsung di pintu masuk area parkir

b) Parking Checkin : Pengemudi melakukan check in dan validasi dengan men-tap kartu RFID di scanner

c) Parking Checkout : Pengemudi melakukan check out dengan men-tap kartu RFID di scanner

D. Rancangan Database

Database yang dibuat mempunyai dua tabel, yaitu tabel parking_spots dan transparking. Berikut adalah desain mockup yang dirancang untuk prototipe Sistem Smart Parking with Reservation.

\begin{tabular}{|c|c|}
\hline \multirow{2}{*}{ Parking_Spots } & TransParking \\
\hline & Id_Trans \\
\hline Id_Spot & Id_Card \\
\hline $\begin{array}{l}\text { Floor } \\
\text { Number }\end{array}$ & $\begin{array}{c}\text { Check_In } \\
\text { CheckŌut } \\
\text { Cancelation_Date } \\
\text { Parkin } \\
\text { Parkout } \\
\text { Updated_at } \\
\text { Created_at }\end{array}$ \\
\hline
\end{tabular}

Gambar 9. Desain database

Ketika user melakukan reservasi pada tempat parkir, maka user harus melakukan scanning terhadap RFID sesuai dengan spot parking yang telah ditentukan. Setelah reservasi, apabila berhasil sistem kemudian akan menampilkan spot parkir yang dibooking dan lokasinya dilayar.

E. Perancangan Antar Muka

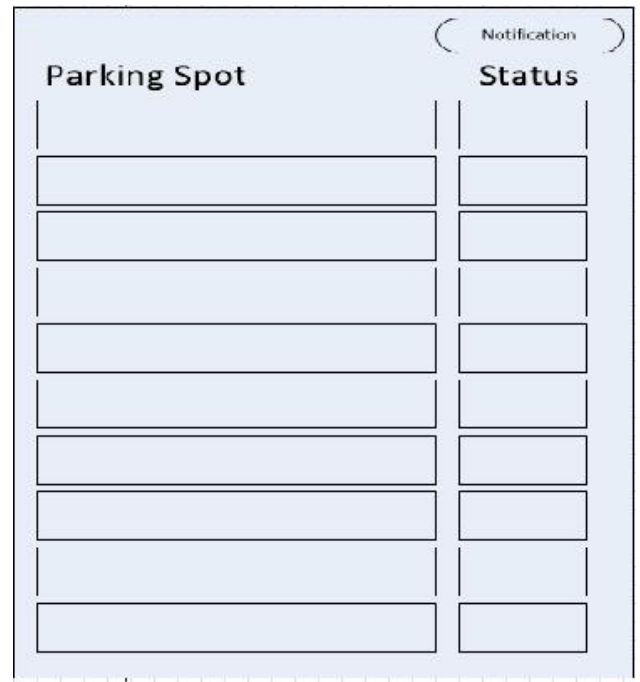

Gambar 10. Interface Layar Petugas Parkir 
Display gambar 10 berada di layar petugas parkir, fungsinya untuk menampilkan status masing masing spot parkir, beserta notifikasi apabila terjadi masalah.

\section{HASIL DAN PEMBAHASAN}

A. Program Reserve Parking

Dibawah ini merupakan program mikrokontroller ESP8266, untuk reservasi tempat parkir.

1. Ketika mobil akan masuk ke dalam kawasan tempat parkir (biasanya berupa gerbang portal), pengendara akan melakukan tap kartu emoney/rfid pada sensor RFID, yang kemudian mikrokontroller akan membaca id dari kartu lalu mengirimkan ke server menggunakan protokol http, server akan mendaftarkan id kartu pada database dan menyiapkan tempat parkir dan di database tempat parkir tersebut dicatat sebagai reserved atau pada sistem akan diberikan status "reserved", nomor tempat parkir akan divisualisasikan kepada pengendara melalui display monitor atau dalam bentuk print out ( proses visualisasi diluar sistem).

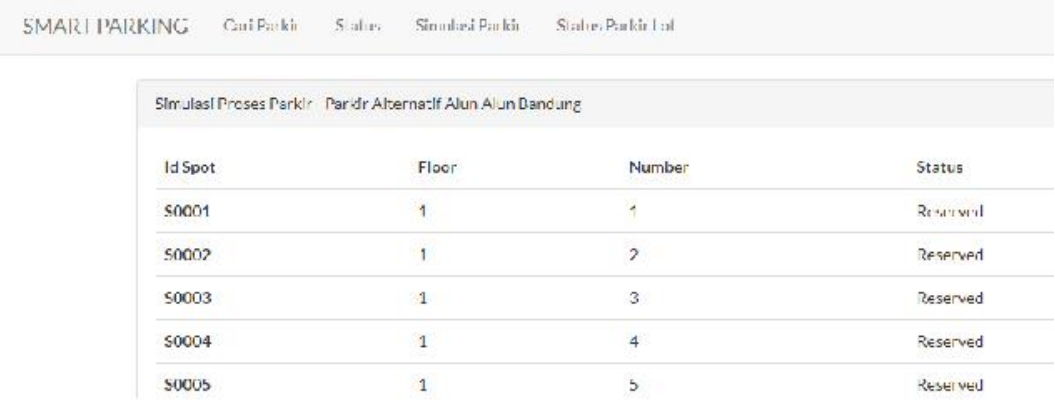

\section{Gambar 11. Interface Server Dashboard untuk Status Reserved}

2. Selain itu ketika pengendara akan keluar dari kawasan parkir, pengendara akan melakukan tap kartu di gerbang keluar, dan mikrokontroller akan mengirim pesan ke server dan server mengubah status tempat parkir tersebut menjadi "available".

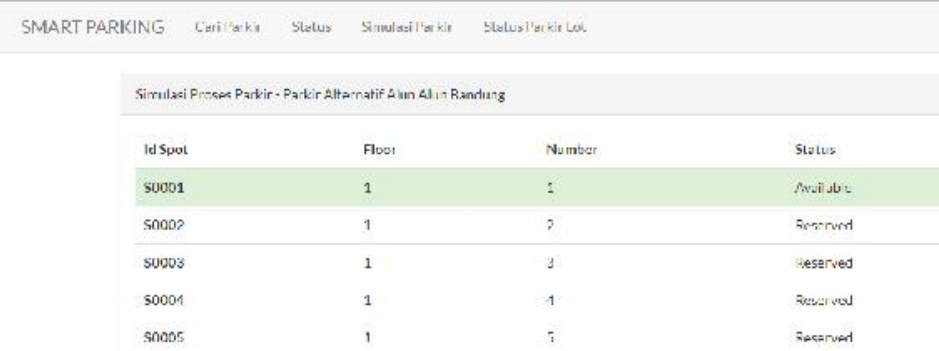

Gambar 12. Interface Server Dashboard untuk Status Available 


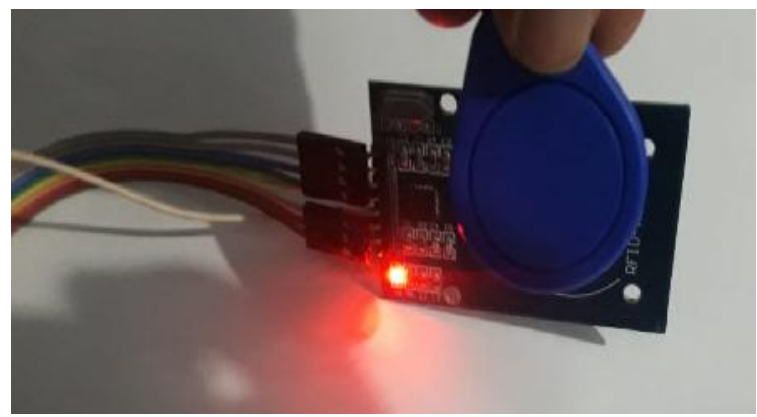

Gambar 13. Tap kartu RFID pada Reader

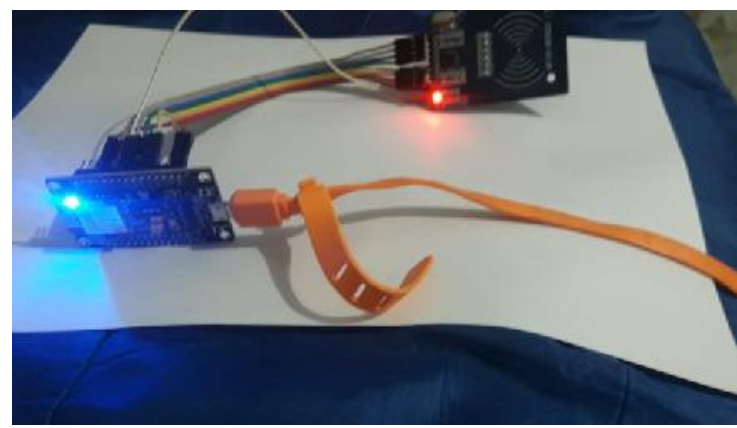

Gambar 14. Alat Untuk Reservasi Parkir pada portal Pintu Parkir (Portal Gate)

B. Program Smart Parking

Di bawah ini merupakan program mikrokontroller ESP8266,untuk identifikasi dan otorisasi mobil pada tempat parkir yang telah di reservasi sebelumnya, ada 3 alur kerja utama dari mikrokontroller tersebut, yaitu :

1. Setelah pengendara melakukan reservasi tempat parkir, pengendara membawa mobil nya ke tempat parkir yang telah ditunjuk oleh server, ketika mobil telah parkir, sensor di tempat parkir tersebut akan mendeteksi kendaraan dan pengendara diberi waktu 15 detik untuk melakukan tap kartu emoney/rfid pada sensor rfid yang berada pada tempat parkir tersebut, sebelum mikrokontroller membunyikan alarm dan menginformasi server bahwa tempat parkir dipakai oleh kendaraan yang tidak berhak dan server akan memberikan status "Waiting User Authenticate", seperti tampilan dibawah ini.

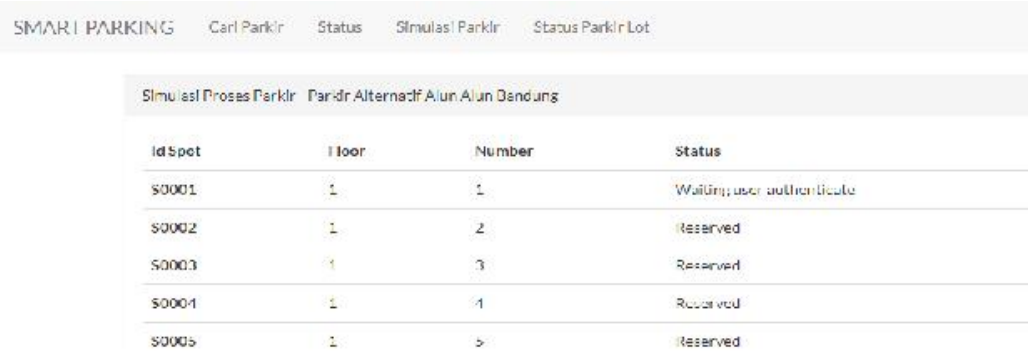

Gambar 15. Interface Server Dashboard untuk Status Waiting User Authenticate 
2. Setelah pengendara melakukan tap kartu emoney/rfid pada sensor rfid yang berada pada tempat parkir sesuai dengan "reserved", maka mikrokontroller akan mengirim data kartu ke server dan server akan mengecek otorisasi dari id kartu apabila berhak maka server mengubah status tempat parkir tersebut menjadi "used".

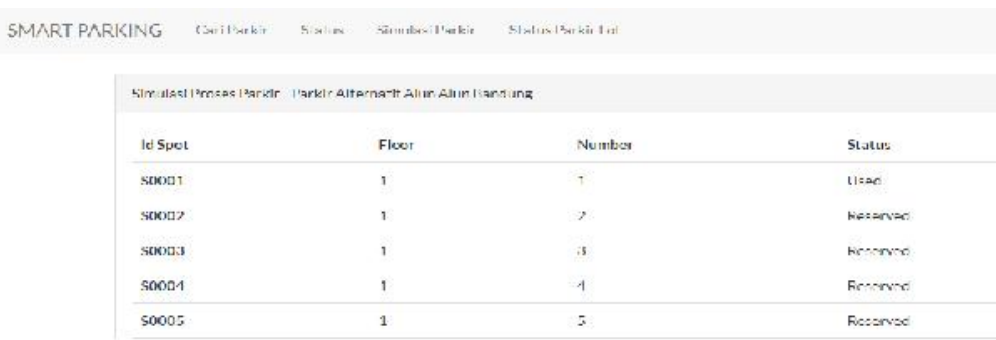

Gambar 16. Interface Server Dashboard untuk Status Used

3. Ketika mobil meninggalkan tempat parkir, sensor akan mengidentifikasi dan mengirim pesan ke server, dan server akan merubah status dari tempat parkir tersebut menjadi “park-out"seperti tampilan dibawah ini.

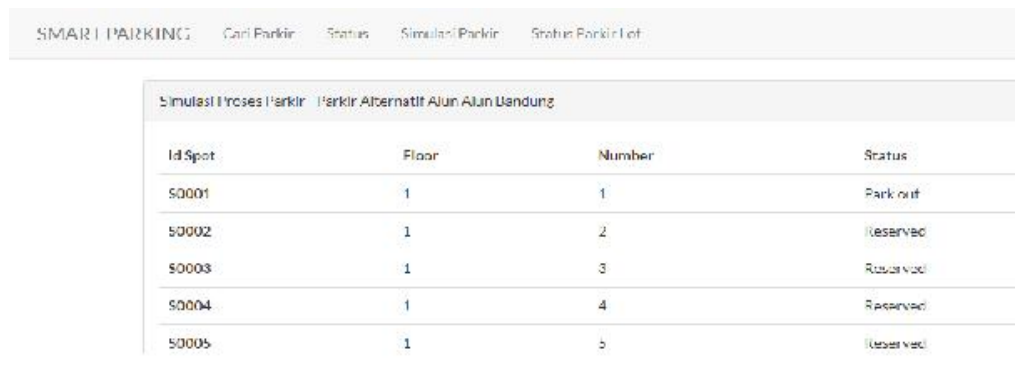

\section{Gambar 17Interface Server Dashboard untuk Status Park out}

\section{KESIMPULAN}

A. Kesimpulan

Berdasarkan penelitian yang telah dilakukan dengan membangun prototipe dari Reservation based Smart Parking System untuk mengoptimalkan manajemen parkir. Diperoleh kesimpulan sebagai berikut :

1. Aplikasi smartparking yang telah dibangun dapat memecahkan masalah kemacetan yang diakibatkan pengendara tidak mengetahui slot parkir dan lokasinya sehingga dapat mengurangi waktu pencarian tempat parkir.

2. Dengan adanya aplikasi smartparking diharapkan pengendara dapat memesan tempat parkir tanpa harus mencari tempat parkir. 
B. Saran

Adapun saran yang dapat penulis berikan untuk pengembangan dari sistem yang telah dibuat antara lain :

1. Pada pengembangan selanjutnya dapat ditambahkan metode pembayaran tarif parkir dengan menggunakan sistem e-money.

2. Prototipe yang dibuat masih untuk satu kawasan parkir tertentu saja, kedepannya diharapkan pengguna jasa parkir dapat melakukan pemesanan slot parkir, sesuai dengan lokasi parkir yang dituju, sehingga kemacetan dapat diatasi.

\section{REFERENCES}

[1] P. White. "No Vacancy: Park Slopes Parking Problem And How to Fix It.” Internet: http://www.transalt.org/newsroom/releases/126 [7 Januari 2016].

[2] Glenn Surpris, Dahai Liu, Dennis . Evaluating the Effect of Smart Parking. Technology on Campus Parking System Efficiency using Discrete Event Simulation

[3] “Sistem Informasi Parkir.” Internet: https://id.wikipedia.org/wiki/ Sistem_informasi_parkir [7 Juni 2018]

[4] Sommerville, I., 2010. Software Engineering. ninth ed. Massachussets: Addison Wesley

[5] Gongjun Yan, dkk. "Smart Parking: A Secure and Intelligent Parking System Using Notice." dalam IEEE Conference on Intelligent Transportation Systems, 2008, hlm. 569-574.

[6] Acedemia edu, "pengertian internet of things", 2015

[7] Murti, Y. (2016). Rancang Bangun Prototipe Pengendali Peralatan Rumah Tangga Menggunakan Arduino dan Smartphone. Skripsi. Universitas Bangka Belitung. Bangka.

[8] Murti, Y. (2016). Rancang Bangun Prototipe Pengendali Peralatan Rumah Tangga Menggunakan Arduino dan Smartphone. Skripsi. Universitas Bangka Belitung. Bangka.

[9] Murti Y (2016), Rancang bangun protitipe pengendali peralatan rumah tangga menggunakan Arduino dan Smartphone, skripsi Universitas bangka dan belitung

[10] Setiawan, Afrie. 2011. Mikrokontroller ATMEGA 8535 dan ATMEGA 16 Menggunakan BASCOM-AVR. Andi:Yogyakarta

[11] Hongwei Wang and Wenbo Hey, A Reservation-based Smart Parking System. The First International Workshop on Cyber-Physical Networking Systems, 2011 dari http://cse.unl.edu/ byrav/INFOCOM2011/workshops/papers/p701-wang.pdf.

[12] Ndayambaje Moses, Y. D. Chincholkar. Smart Parking System for Monitoring Vacant Parking, June 2016, dari http://www.ijarcce.com/upload/2016/june-16/IJARCCE\%20159.pdf

[13] Glenn Surpris, Dahai Liu, Dennis, Evaluating the Effect of Smart Parking. Technology on Campus Parking System Efficiency using Discrete Event Simulation, 2012. 